\title{
FLOWERS OF THE PEACE RIVER COUNTRY ROADSIDES
}

by Dorthea H. Calverley, 10209 14tth Street, Dawson Creek, B.C.

During the years 1955-1966, inclusive, I have collected wild flowers in the Peace River country. This year as a centennial project the Girl Guide Association of Dawson Creek under the supervision of Mrs. F. P. Flack, 1317 93rd Avenue, has typed and assembled a list of this collection. The stencils are still available so extra copies can be obtained by writing to the author in Dawson Creek. It is my hope that this list may induce some botanist to make a complete and scientific survey of the area. At the rate at which clearing and cultivation is proceeding, less time is left for this than one would wish.

The list is not a complete list of all the wild flowers of the area. It includes only those which can be reached on foot, from a car, by a collector whose agility is considerably impaired by advancing years. A few mountain species were brought down by Roderick Calverley but the mountains of the area are scarcely touched. The list does not include grasses, sedges, common weeds, or marsh and muskeg plants.

The Peace River country covered by this list includes the easily travelled roads of the British Columbia area as far west as Hudson's Hope and Lake Azouzetta, as far north as Rose Prairie and Cecil Lake, and as far south as Sukunka Falls and Puggins Mountain. Since the Kliskun Hills are so close to the British Columbia boundary, this unique and interesting area has been included. Within this area there are still many places to be explored.

The list, arranged by families, includes the common name, the scientific name, brief notes on where found and abundance and earliest recorded flowering dates. The scientific names were supplied by the Provincial Museum of British Columbia or by the Botany Department of the University of Alberta. Pressed specimens of the plants listed are in the Provincial
Museum in Victoria. I am deeply indebted to Dr. Adam Szczawinski, Provincial Botanist and to his assistant, W. Savale, for their kindness in identifying more than five hundred specimens.

In the radius of an afternoon's drive, one may sample prairie, muskeg, mountain, forest, "bush", "badlands" and sub-arctic habitats. Blendings and overlappings of these habitats may produce variations and subspecies. For example, Anemone patens, commonly called the crocus, may look, to the casual southern prairie visitor, exactly like the ones he knows at home. It may puzzle him to find this dweller of dry prairie sod growing in profusion under the pine woods near the Portage Mountain dam. Actually this is a distinct variety, Anemone patens L. multifidia (Pritzel) Zamel.

The Pouce Coupe Hills and the Bear Hills south of Dawson Creek have been explored only enough to show that unexpected plants may be found at top elevations and on their southern slopes. For example, although the trillium is considered very improbable at this latitude, three careful observers have reported that this plant has bloomed here. Since I do not have a voucher specimen the trillium is not included in the present preliminary list.

The assistance of Howard and Roderick Calverley is gratefully acknowledged, also that of Mrs. Janet Paul, Mrs. Anna Mantle, and many other friends who directed me to new finds, or brought specimens in to me. And thanks again to the Girl Guide Association for putting this material into usable form.

[EDITOR'S NOTE: Mrs. Calverley, who kindly sent us a copy of the list, writes that as Dorthea Horton she lived in Saskatchewan while it was still Northwest Territories, and that she taught for many years in Swift Current Collegiate.] 